\title{
A STUDY ON ADEPT SOFT SKILL \& KNOWLEDGE ACCOMPANYING HOSPITALITY EMPLOYEE RETENTION BEHAVIOR DURING COVID-19 LOCKDOWN PHASE
}

\author{
Salla Vijay Kumar*
}

\begin{abstract}
This article converses the acceptability, challenges, and cue forward on hotel employees' through academic research on digital literacy. Abstract researcher intends to study the correlation between personalized training customized by organizations and self-learning digital transformation which has shown its prominence during the unprecedented lockdown phase. The article also tries to emphasize labor flexibility and participation in decision making through various communication channels working in a conducive environment. The bibliographical review studies depict hospitality education, employment, and manpower development as some of the concerns being faced in the digital generation. The results of studies conducted show employee's digital competence as a catalyst to their productivity. They have reinforced and expanded the horizon of the employees to run with the advancement. Paul Gilster (1977) in his book has represented digital technologies as an "essential life skill." The conclusions are that there is an increase in understanding, using, and creating information sources using digital technologies in the tourism sector. The new-gen hoteliers are themselves keeping abreast with the latest innovation in procedures and practices to offer the service or product through the digital presence and retain the customers. Through this paper, the researcher would like to relate e-HR developmental approaches, customer relations management, and retention modeling as a tool for sustainable workforce investment.
\end{abstract}

Key words: Hospitality; Digital; Literacy; Retention; Crisis; Knowledge.

\section{UM ESTUDO SOBRE HABILIDADES E CONHECIMENTOS ESPECIALIZADOS QUE ACOMPANHAM O COMPORTAMENTO DE RETENÇÃO DE FUNCIONÁRIOS DURANTE A FASE DE FECHAMENTO DA COVID-19}

Resumo

Este artigo fala sobre a aceitabilidade, os desafios e as sugestões dos funcionários do hotel através de pesquisas acadêmicas sobre alfabetização digital. A pesquisa pretende estudar a correlação entre o treinamento personalizado personalizado por organizações e a autoaprendizagem da transformação digital que tem mostrado seu destaque durante a fase de bloqueio sem precedentes. 0 artigo também tenta enfatizar a flexibilidade laboral e a participação na tomada de decisões através de vários canais de comunicação trabalhando em um ambiente propício. Os estudos de revisão bibliográfica retratam a educação da hospitalidade, o emprego e o desenvolvimento da mão-deobra como algumas das preocupações que estão sendo enfrentadas na geração digital. Os resultados dos estudos realizados mostram a competência digital dos funcionários como um catalisador para sua produtividade. Eles reforçaram e expandiram o horizonte dos funcionários para que funcionassem com o avanço. Paul Gilster (1977) em seu livro representou as tecnologias digitais como uma "habilidade essencial para a vida". As conclusões são que há um aumento no entendimento, uso e criação de fontes de informação usando tecnologias digitais no setor de turismo. Os novos hoteleiros estão se mantendo atualizados com as últimas inovações em procedimentos e práticas para oferecer o serviço ou produto através da presença digital e reter os clientes. Através deste trabalho, o pesquisador gostaria de relacionar as abordagens de desenvolvimento e-RH, gestão de relações com clientes e modelagem de retenção como uma ferramenta para 0 investimento sustentável da força de trabalho.

Palavras-chave: Hospitalidade; Digital; Alfabetização; Retenção; Crise; Conhecimento.

\section{UN ESTUDIO SOBRE LAS HABILIDADES BLANDAS Y LOS CONOCIMIENTOS QUE ACOMPAÑAN EL COMPORTAMIENTO DE RETENCIÓN DE LOS EMPLEADOS DE LA HOSTELERÍA DURANTE LA FASE DE CIERRE DE COVID-19}

Este artículo habla de la aceptabilidad, los retos y las señales de los empleados de hoteles a través de la investigación académica sobre la alfabetización digital. El investigador pretende estudiar la correlación entre la formación personalizada por las organizaciones y la transformación digital de autoaprendizaje que ha mostrado su protagonismo durante la fase de cierre sin precedentes. El artículo también trata de enfatizar la flexibilidad laboral y la participación en la toma de decisiones a través de diversos canales de comunicación trabajando en un entorno propicio. Los estudios de revisión bibliográfica describen la educación en hostelería, el empleo y el desarrollo de la mano de obra como algunas de las preocupaciones a las que se enfrenta la generación digital. Los resultados de los estudios realizados muestran que la competencia digital de los empleados es un catalizador de su productividad. Han reforzado y ampliado el horizonte de los empleados para correr con el avance. Paul Gilster (1977) en su libro ha representado las tecnologías digitales como una "habilidad vital esencial". Las conclusiones son que hay un aumento en la comprensión, el uso y la creación de fuentes de información utilizando las tecnologías digitales en el sector turístico. Los propios hoteleros de nueva generación se mantienen al tanto de las últimas innovaciones en procedimientos y prácticas para ofrecer el servicio o producto a través de la presencia digital y retener a los clientes. A través de este trabajo, el investigador quiere relacionar los enfoques de desarrollo de los e-HR, la gestión de las relaciones con los clientes y el modelo de retención como herramienta para la inversión sostenible de la fuerza de trabajo.

Palabras clave: Hostelería; Digital; Alfabetización; Retención; Crisis; Conocimiento.

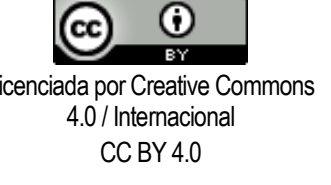

* Ph.D Scholar, Kadi Sarva Vishwavidyalaya, Gandhinagar. Master of Philosophy in Tourism Management/MKU (2009). Master
in Tourism Management /MKU (2007). Degree in Bachelor of Science - Hospitality \& Hotel Administration/IGNOU (2007),
Diploma in Hotel Management/NCHMCT (1996). Senior Lecturer cum Senior Instructor) in Bachelor of Science - Hospitality
\& Hotel Administration/IHMA (2002 onwards. National Awardee - Best Teacher-Hospitality Education/MoT, GOI (2008-09).
Aspiring Researcher Awardee/IHC (2017). Award of Excellence in the field of Tourism \& Hospitality/IHC (2018). Lectures
telecasted live on Food Production/IGNOU-Edusat (2011). Author of Academic, Hospitality and Non -Hospitality Articles/
VARIOUS (2012-2021). Research Scholar publications of various papers/PAN INDIA (2015-21). Core Research Member of
consulting hospitality projects (2020). Life Member/ ICSL (2019), RCS (2012), ASCI (2010). CV profile :
https://www.linkedin.com/in/salla-vijay-kumar-34129a37/ [ sallavijaykumar75@gmail.com ]

Rev. Anais Bras. de Est. Tur./ABET, Juiz de Fora (Brasil), e-ISSN 2238-2925, v.11, n. único, pp.1 - 9, Jan./ Dez., 2021 


\section{INTRODUCTION}

It is imperative in any field to up-skill to stay adept, whether in education or operations. Every employee has to earn their keep by competency building and technological advancement sync. Technical education in hospitality and tourism paves the way to employability ready-to-delivergraduates.

The hospitality graduate /fresher job assignment entails a set of duties and responsibilities at the workplace. Digitalization has had a gradual growth ever since. Many organizations adopt continual education or competency tests, to learn, share and grow with the organization to keep up with the fast pace of industrial and hospitality technological changes.

The digital computers were restricted to the business centers in the hospitality units for the sole use of the front office personnel, top management, and the guests (Alford \&Jones, 2020; Conrady \&Buck, 2007; Beckendorff, Xiang \& Sheldon, 2019). Later it came down to all departments and the training and retraining came into existence. They have reinforced and expanded the horizon of the employees to run with the advancement.

As Paul Gilster (1977) notes, digital technologies as an essential life skill. The new-gen hoteliers are themselves keeping abreast with the latest innovation in procedures and practices to offer the service or product through the digital presence and retain the customers.

The same is true in digital technology and marketing to ensure the best of the services being provided. This in turn increases efficiencies of the employees and increases revenues. The productivity becomes directly proportional to allow people to interact and communicate with colleagues, family, and friends regularly even though with the "busy constraints" of today's world (Molz 2012).

Many researchers and authors have explored the interrelationship between employees in the organization and the extent to which digital technologies are helping the mannerism of the work. Rising to the next level of knowledge, skill, and attitude inputs acquisition helps the engagement for a longer tenure. It lingers in the thought of how digital technologies drive engagement and what is HR's role in stewarding the work of enabler for digital engagement in the modern workforce (Gretzel 2011; Jesuthasan2017).

\section{LITERATURE REVIEW}

The skills can be further categorized as the core competencies, basic skill, work skills, hard skills, generic skills, enabling skills, transferable skills, essential skills, soft skills, key skills, and personal skills (Department of Education Science and Training [DEST], 2006; Fujimura, 2004; Knight \&Yorke, 2002); and employability skills (Sin and Neave 2016; Lunt 2006). In the hospitality education, Student Identity Formulation In considering employability skills development of students, Chickering's Theory of Student Development (1969) serves as an appropriate conceptual frame.

Fig I - Chickering's Vectors of student development Linkages to Employability Skills.

\begin{tabular}{|c|c|}
\hline $\begin{array}{l}\text { Vectors Of Student } \\
\text { Development }\end{array}$ & Employability Skills \\
\hline $\begin{array}{l}\text { Developing } \\
\text { competence }\end{array}$ & $\begin{array}{l}\text { Communication, Work Culture, } \\
\text { Professional Qualities, } \\
\text { Teamwork, Analytic skills, } \\
\text { Learning Theory and Practice, } \\
\text { Organization/ Planning }\end{array}$ \\
\hline Managing emotions & $\begin{array}{l}\text { Work Culture, Professional } \\
\text { Qualities, Teamwork }\end{array}$ \\
\hline $\begin{array}{lr}\text { Moving through } \\
\text { autonomy toward } \\
\text { interdependence }\end{array}$ & $\begin{array}{l}\text { Work Culture, Leadership, } \\
\text { Professional Qualities, Teamwork }\end{array}$ \\
\hline $\begin{array}{l}\text { Developing mature } \\
\text { interpersonal } \\
\text { relationships }\end{array}$ & $\begin{array}{l}\text { Work Culture, Leadership, } \\
\text { Professional Qualities, Teamwork }\end{array}$ \\
\hline Establishing identity & $\begin{array}{l}\text { Communication, Work Culture, } \\
\text { Leadership, Professional } \\
\text { Qualities, Teamwork, Analytic } \\
\text { skills, Learning Theory and } \\
\text { Practice, Organization/ Planning }\end{array}$ \\
\hline Developing purpose & $\begin{array}{l}\text { Analytic skills, Learning Theory } \\
\text { and Practice, Organization/ } \\
\text { Planning }\end{array}$ \\
\hline Developing integrity & $\begin{array}{l}\text { Communication, Work Culture, } \\
\text { Leadership, Professional } \\
\text { Qualities, Teamwork, Analytic } \\
\text { skills, Learning Theory and } \\
\text { Practice, Organization/ Planning }\end{array}$ \\
\hline
\end{tabular}

Source: Chickering, A. W. (2000: 23-32).

Some common practices on-the-job are:

- Step1 - Define conceptual boundary objectively as per area of specialization;

- Step2 - Subjective explanation of the detailed assignment;

- Step3 - Performance and feedback;

- Step4 - Training \& continual follow up.

The all-time inclusion of information communication technology has upgraded the level of the performance and in the process of training and retraining could have helped retain the tech-savvy employees. Sigala (2002), reviewing several studies on the use of ICT in education, emphasizes this capability, arguing that "the intellectual synergy of many minds, 
experiences and knowledge" fosters, among other benefits, improved individual achievement. . . critical thinking, diversity of ideas and students' long-term retention".

The intention to stay is intrigued by the quality of technology-enabled learning, proactive human behavior and facilitate the sharing of expertise to a greater target audience in different geographic locations. There have been various research studies about tourism and hospitality education in India. With hospitality as an immaculate element of tourism education, there is a scope of hospitality and tourism development of the particular region (Bagri and Babu, 2009).

The degree accomplished in the hospitality and tourism sector have proved to be very important in developing right kind of human as a resource for better planning and develop a requisite degree of professionalism to industry (Bhardwaj, 2002).

There have been issues around hospitality education viz., lack of uniformity and standardization of courses as a common entity on the service providers that creates the gap between the academia and industry (Amoah and Baum, 1997; Korstanje 2012; Airey, Tribe, Beckendorff and Xiao 2015). The variableness in terms of syllabi and dissemination resultant are predictors of employment prospects (Bagri and Babu, 2009); failing to meet the expectation of the industry (Baum, 1995).

The major workforce of the hotels is constituted by the hospitality graduates of varied areas of specializations and have extended to other related sectors, - non-retail, hospitals, retail, MNC, real estate, armed forces, information technology, banking, sales and marketing to name a few. The lockdown has seen the hotel chains and industry analysts cutting back on their growth forecasts for the current quarter (April June 2020). The tourism business and leisure trip have had cancellations and the conferences/exhibitions hampered and would regain up to $50 \%$ post-COVID lockdown somewhere mid next year 2021.

The market segmentation of the small and medium enterprises such as bed \& breakfast, hostels, pubs $\&$ clubs, cafés, restaurants, bistros and beach bars wherein being a small family business are very likely to live the crisis and intrinsically vulnerable to change. The opportunities in this crisis are the change in landscape and mindset in the hotel trends. The Forward-thinking hoteliers should always be aware of the leading industry trends: like

- Vacation rentals

- Home-sharing - Personalized home stays version

- B leisure

- Eco-friendly concepts

\section{BRIDGING THE GAP}

We have always been behind soft skills; grooming standards, etiquettes, dress codes, and language, interpersonal self as relationships rely on social skills. All of this carries impetus to the devotion and dedication quotient. These skills offer means of interacting with others that help boost productivity, improve relationships, and increase ones general quality of life.

Social skills can also be called 'people skills'. Looking forward to the contemporary human capital enterprise restoring respectability and being identifiable. Most employees believe in the theory of learning through training as the most common HR entity is a valued commodity in the business world to grow. Some personalized training customized by organizations are:

- Micro-learning segments - Learning in small digestible chunks

- Adaptive learning - subordinate - superior learning

- High-tech learning systems - is the necessity of the hour

- Self -Learning through professional certified online service providers

The digital transformation has started building a hybrid workforce in the hospitality operations and it has only increased with the advent of the pandemic, social distancing and hygiene features. The absence or lesser involvement of the employees in hospitality and tourism are serving the purpose of catering to the guests, tourists and corporate, where a professional is provided with real-time data to decipher and decide by the Alpowered tools, the professional program the applications to complete a particular task for eg: registration, express check-in/ check-out and menu ordering etc.

A case study of McDonald's Corp. recently launched on-demand training with an online program called Fred, named after Fred Turner, a former senior chairman of the fast-food chain and the founder of Hamburger University. Until late, McDonald's still printed and shipped paper training manuals to its tens of thousands of franchisees, offered required employees to use a desktop computer. But after hiring San Francisco-based Inkling to help digitize its offerings, it became digital and that allows employees to access the module about relevant topics, such as how to fix a fryer. These programs come for a cost based on the scope of the training, several employees, and other factors. The Association for Talent Development puts organizations' current direct expenditures for training and development at $\$ 1,252$ per employee. 
There have been barriers to the digital inception from the employees like resistance towards transformation and lack of willingness to collaborate. Digital transformation can be most difficult in traditional organizations with a long-running history of success and low employee turnover.

\section{ONBOARDING}

Good onboarding is a key for success for any organization, with the three aspects of preboarding, orientation, and onboarding emphasizing to make sure new employees know how to contact their direct manager, their colleagues, and their HR manager if they have any questions. Burne and Marris (2015) reinstate that new technologies transform the dynamics of tourism from its operation as a model to its administration as a service.

Are porton US employee retention statistics 2019 by Darko Jacimovic stated even if $69 \%$ of employees would improve their performance if their efforts were appreciated. $45 \%$ of millennials would quit a job that uses substandard technology, but we need to address the issue that the hotel and motel industry has a turnover rate of $73.8 \%$, and employee recognition programs can reduce the turnover rate by up to $31 \%$.

The major concern and responsibility of the management and the HR department are to connect with the employees during the due course of their engagement in the hotel. It becomes a professional tieup in the time of adversity and challenges.

The personnel got upgraded to human resource and I presume it can again be a personalized one to one personnel stakeholder's management during the COVID-19 period. More than business profitability and running competition in the unprecedented phase, the need is to create a positive bond to stand with the employees who stand by the organization.

So, HR needs to perform multiple roles when it comes to people related. Skilling/ Reskilling/ Up-skilling

- COVID period has made HR rethink certain issues regarding motivating, inspiring, and training, and developing the people and adoption of a system of imparting skilling (learning new skills for being competent in upcoming days, adversity or adversity, or any crisis); up-skilling (learning current tasks more deeply); as this is the need of the hour to learn and understand new technology as well as manage relationships to fit into the changing scenario and economic landscape.

People need to be updated on technology, design thinking, analytics, storytelling, and artificial intelligence, etc. People at the grass-root level and working at lower-profile are required to be trained on accomplishing their tasks and reporting about their developments to their supervisors either by mobile or any other platform. So, this way, making people competent and multi-skilled in a variety of ways and enhance their skill sets.

Employers, as well as HR, need to play a very pivotal role in creating a bond with the people under the "People connect 'concept and need to connect people from grass root level whom they have always ignored. The term has come to re-imagine HR as stakeholder management during COVID-19 period. They need to realize this fact very seriously that money is not everything but to create a positive bond with them. So HR needs to perform multiple roles when it comes to related people.

Skilling/ Reskilling/Up-skilling - COVID period has made HR rethink certain issues regarding motivating, inspiring, and training and developing the people and adoption of a system of imparting skilling (learning new skills for being competent in upcoming days, adversity or adversity, or any crisis); up-skilling (learning current tasks more deeply); as this is the need of the hour to learn and understand new technology as well as manage relationships to fit into the changing scenario and economic landscape.

People need to be updated on technology, design thinking, analytics, story telling, and artificial intelligence, etc. People at the grass-root level and working at lower-profile arerequired to be trained on accomplishing their tasks and reporting about their developments to their supervisors either by mobile or any other platform.

So, this way, making people competent and multiskilled in a variety of ways and enhance their skillsets. The unprecedented and the economy have directly affected employment in the form of retention or downsizing.

There has been a lot of illustrations in this regard. Everyone is being democratic and fortune teller on the post COVID-19 business plan and the measures to be taken to achieve the normalcy but many so a scope of inconsistent and unrealizable in the approach of the practicality aspect. The hotel asset management team can provide best practices and adapted approaches to each particular hotel.

\section{INSTANTANEOUS LOYALTY PROGRAM}

The corporate belongingness in international hotel brands includes the relevant element of employee caring. For example, Marriott hotels have devised a concept of people first and their value is "Take care of our associates and they will take care of our customers."

Besides the written contract, the hotel chains have built psychological contracts with their employee 
that creates unwritten expectations in the employment relationship. Organizations are set to rethink seating arrangements on social distancing at workplaces, lesser to the no-touch common surface, go digital with meetings/ discussions/ dialogue, frequent sanitization, and stationed hand sanitizers, and have plans for places of contact like biometric, doorknobs, crockery cutlery, and stationery.

The Covid-19 phase operations have seen the paradigm shift to digital systems and the adaptability has been rather less than a short-term course and the resultant skill acquisition is above cent percentage. The sections of the hotels have been temporarily converted to medical hostels for the quarantine of patients.

In these multidimensional hospitality operations, manpower enterprise is the biggest asset holding, so damage to them can affect the organization as a whole. This is the time when the hotels show respect for the association towards their well-being and work-life balance.

For instance, Hilton has announced that it will team up with 30 leading companies to provide temporary jobs, in addition to the common practice of covering health benefits.

Furthermore, Accor will allocate EUR 70million in a fund to cover those employees without medical insurance or social security that present COVID-19 health issues and to support front-line healthcare professionals \& non-profit organizations. The fund has been raised from the unpaid year 2019 dividends.

The determination to maintain follow-up support during the challenges leads to the recovery phase. There is time as mentioned earlier to get back to normal operational business and celebrate the people talents in the industry once the market starts torecover.

Organizational brand image and commitment go hand inhand especially when they support them during tough periods. When occupancy has drastically come down to nil and closure of properties or single digits at some places, the fund earned are not meeting any fixed/ scheduled expenses. multiple hotel chains including property chain hotel giants like Marriott, Hilton, Hyatt, etc have announced furloughing schemes as a component of their COVID-19 responses to slash costs.

Furthermore, these hotel chains have also declared a different degree of pay cuts for the remaining employees depending on thelevels. Abdin \& Kumar (2020) stated economic efforts will be needed from all the quarters to restore balance to the Indian economy.

For example, CEOs put a halt to cash dividends and reduced salaries to senior executive teams by $50 \%$. A salary cut policy is required at every level to survive and sustain the loss at the same time gear up the process once again with greater efforts by the management and employees to reap the benefits again. When some have only shunted employees and many employees have been loyally stuck to their organizations, addressing the expenses and being sustainable competence is a matter of pro-active debt service in place.

\section{TEAM OPTIMIZATION}

Team optimization is imperative with the available talent in hand while reducing long term costs and often improves the overall operation/guest experience. The medical facilities considered to be a need of utmost importance at this hour of lockdown could be beneficial but incur a huge cost to the company only to assure the workforce for better condition post the challenging times.

The cost of training has been affected as the major business is at standstill but self-training of the digitalization through the lockdown protocol have equipped the employees who chose to stay and serve. The major fear now is a shortage due to layoff, retrenchment and for those employed the fear of infection to resume.

There have been measures to curtail the fear and also strategies to spread a sense of confidence in the guests but it will take time to overcome this problem. Thorough training at this hour of the second wave and on the verge of vaccine availability will have a direct positive impact on productivity, customer satisfaction, revenue growth through up selling and enhance employee satisfaction that leads to lower turnover.

The hybrid training can have its set of advantages:

- Improve communication by providing a centralized digital platform;

- Provide recognition by validating task completion;

- Productivity planning can bridge the gap between management and the staff;

- Reduce the decision making response time.

Recognition and career advancement systems through digital adoption at the workplace can have a positive effect on individuals and the teams within. Having a talented pool of employees is a key success factor for any organization to achieve to reach the highest levels of performance.

Unfortunately, it is also one of the most difficult objectives to accomplish, with the demand for digital acquired talent always high both inside and outside the company. This can be helpful to the hotel service provider in retaining their employees by understanding the digital adoption measures and collaborative environment that would enhance employee retention. 


\section{THE STRATEGY}

The strategy for successful and sustainable hotel operations is dependent on the survival minimum which is the crisis management in terms of manpower. The covid lockdown and natural and political and climatic influences have taught us that the task that was done by the number of people could be reduced and with the minimum manpower or cross-functional staff, the tasks can be accomplished with minimum training athand.

While the survival minimum is a necessary activity to function as a business that acts as the major skeletal framework, the strategic optimum are the additional activities critical to the achievement of strategic goals. The up-gradation of the survival minimum to strategic optimum is situationally illustrated. These have been exercised unlike the traditional/incremental approac hof the employees. This has also roved resilience and improved level of satisfaction amongst being assured of being taken careof.

While the factors affecting the intention to stay and reasons to look for another job have had an indefinite concern, HR has been instrumental in addressing the recognition, appraisal, promotion, and pay including incentives and entertaining periodic leaves and job rotation to properties in the chain. This has had an all-rounder concept, worked by Marriott as Voyager program.

This not only gives a zest of departmental responsibilities and interdepartmental cooperation but also readiness to perform in any department with a varied job profile frontline to the back of the house. A study by Dachary. et al. (2020) states this business entity as a new social relationships in a digitally controlled society.

There is an emotional connection between the job satisfaction created with the engagement and the degree of intrinsic motivation invoked by their jobs. It will not be concluding to note that the level of satisfaction is directly proportional to the employee's organizational commitment. Here could be reasons often work-related factors that play a crucial role in determining the satisfaction index.

Giancola (2009; see also Scott et al. 2012) notes a total rewards system includes "five elements in the work experience to be combined to form an organization's rewards strategy and integrated with the broader human resource strategy". Non financial outcomes have also been referred to as "relational returns" and have been found to have a significant effect on employees' behaviors (Milkovich et al. 2004).

Two additional factors need to be highlighted. First, and specifically for young new employees, an organization should not only build realistic expectations by using realistic job previews (rjps) but also use onboarding to highlight how it intends to meet those expectations.

Second, organizations with strong highperformance and high-commitment cultural values, founded on the principles of organizational justice and fairness, send a loud signal to a diverse workforce that managers intend to retain critical talent. HR Practices to Hinder Competitors from Poaching Critical Talent departments and industries face a high demand for scarce talent.

Silva \& Moreira (2020) stated companies can implement measures to meet the highest standards and, thus, can even aim to increase their profits and/or at least reduce their risks. The talent scarcity naturally causes competitors to poach talent from other companies. They also may use educational background or past work experiences as a deterrent to assess an employee's talent. It also ensures the longevity of the tenure possible.

All organizations are driving their HR department for a positive outcome in terms of services and product delivery and capitalize on the skill pool in store. For example, by using teams of employees with complementary skills, it becomes harder to decipher the contributions of a particular employee.

The employees always look forward to growth also in terms of position and upward movement in the workplace. There have been instances wherein there is no increase in the pay but responsibilities have been assigned and acknowledged though with time-bound goals. This is very important not to allow germination of the idea of turnover or the discussion of attrition in the minds of the employees. This is simply possible with the concerted efforts of the management, $H R$, and the team as a whole in developing a connection.

Once struck can lead to dissatisfaction which will affect productivity and spoil the work culture of the organization. Some aged employees have resented to their entire professional tenure in a single property, but the new-gen employee has a wavering mindset with a bag full of expectations and an unlikely unfriendly work environment can lead to looking for options outside the organization.

Finally, a business could use legal hurdles to deter critical talent from seeking jobs with competitors. The control of the turnover behavior is affected by several factors that are not under the control of the organization but have to be proactively addressed. Innovations and employee-friendly practices have gained confidence in the system of pay for knowledge, innovation-based incentives, and job/communitybased embeddedness to reduce the dysfunctional turnover. Emerging trends, based on a century of research on turnover, support this logic too (Hom et al. 2017). 
The respect for the skill from the individual capacity towards organizational capacity thereby strengthening the community capacity by large. The implications of any assignment should end with societal concern and retaining talent.

\section{CONCLUSIONS}

The entry-level management /management-intraining graduates are made aware of the level of digitalization in hospitality employability operations. It is understood that with the advancement of the ICT the approach and thinking and decision-making patterns tend to alter for good, so through this paper we would like to relate to the sustainability of the manpower development as a whole and e-HR developmental approaches, customer relations management and retention modeling.

Rewards have always been a source of satisfaction for a job well done and also recognition could include both technical and financial rewards to help retain strategic talent. The employees have implemented the digitally transformed organizations of the near future ion this hour of unprecedented lockdown. Some organizations can retain dedicated loyal employees to reap the rewards resulting from the digital transformation of our society.

\section{Practical Suggestions for Tourism Crisis}

\section{Accommodation Facility}

One of the major reasons for people to move away from their homes is employment. The manpower has acquired skill by experience at a lower or unorganized sector but when they are ready to upgrade to the organized hotel sector, a deterrent is that of the accommodation being facilitated by the hotel authorities that not only assures the employability but also reassures the long-term association of the employee.

\section{Training and retraining}

Every individual whether fresher or experienced goes through a probationary term wherein she is trained with the standards of the hotel organization and the adaptability of the environment helps to escalate productivity and the process of decision making at the workplace. As a manager, do not be shy about asking about their career aspirations and their long-term goals.

\section{Regular one to one communication}

Very important is the communication between superiors and subordinates at the workplace. Whether the communication required is horizontal or vertical by need and issue, it is the dialogue that matters to find the solution of a problem or plan.

Garcia (2013) concluded that tourism is an expression of the consumer society and accompanies the efficiency and technological advances in communication. Conversations between the management and the employees can be termed a exist interviews wherein the working condition issues can be heard and resolved for the benefit of the employee thereby the organization as a whole.

The concern of being heard automatically gives a sign of acknowledgment even if the solution proposed is not executed by the authorities. This helps to build a better resilient relationship and display an investment pool of employees that provide intangible benefits that can be rare to find in competing workplaces.

\section{Organizational Brand Image}

One of the tasks of HR department is to create a pool of multi-skilling talent so that they can be absorbed at the time of necessity. The aspects that are predictors of retention of an employee would comprise of the foremost competitive pay and benefits. Other factors should include:

$\checkmark$ Performance appraisals and promotions;

$\checkmark$ Supervisor subordinate interdepartmental cooperation;

$\checkmark$ Training and development programs.

\section{Career advancement}

Every employee desires to grow professionally. The training or retraining need when identified and forged the retention of existing employees through opportunities for promotion and career development provided by the organization.

\section{Community Investment}

The investment in the right fit for any job and assigns the right assignment as per his/her skillset matters a lot. Organizations can attract potential talent by retaining the existing employees through various measures of participation in the decision-making process and exit interviews etc. help to inculcate a harmonious work culture within your hotel.

Corral \& Rodriguez (2015), implied that providing essential information for the evaluation of new strategies. Sound staffing strategies are in place in many organizations working with customized manpower strength lower than the optimum requirement; this has come when the employee feels that the organization is investing in him her. 
Maintaining hygiene and social distancing and calling people at the workplace in urgent cases on alternate days especially in manufacturing units $\mathrm{HR}$ to rethink certain issues regarding motivating, inspiring and training and developing the people and adoption of a system of imparting skilling (learning new skills for being competent in upcoming days, adversity or adversity or any crisis ); up-skilling (learning current tasks more deeply); as this is the need of the hour to learn and understand new technology as well as manage relationships to fit into the changing scenario and economic landscape.

It is commendable that the hotel employees without formal training and knowledge of the unprecedented lockdown have stood by the hotels as a pillar of professionalism. There will be many revival plans but may not be effective. Incomplete job assignments and performance may lead to frustration or stress.

Don't just execute workmanship but study the market and the contingency of the time limit management will help succeed. Instead of layoffs and major pay cuts, it is time for respect for employees, employers, and management as a whole to provide work life balance to spend time for hobbies or brush talent.

\section{REFERENCCES}

Abdin, M.S., \& Kumar, R., (2020) Current Issues on Tourism and Thematic Issue: "Crisis and Uncertainty in Pandemic Times", Revista Anais Brasileiros de Estudos Turísticos - ABET, e-ISSN 2238-2925, v.10, n. único, pp.1-11.

Airey, D., Tribe, J., Benckendorff, P., \& Xiao, H. (2015). The managerial gaze: The long tail of tourism education and research. Journal of Travel Research, 54(2), 139-151.

Alford, P., \& Jones, R. (2020). The lone digital tourism entrepreneur: Knowledge acquisition and collaborative transfer. Tourism Management, 81, 104139.

Amoah, V. A., \& Baum, T. (1997). Tourism education: policy versus practice. International Journal of Contemporary Hospitality Management.9(1): 5-12

Bagri, S. C., \& Suresh Babu, A. (2009). Career in Tourism Administration. Employment News, 33, 46.

Baum, T. (1995). Managing human resources in the European tourism and hospitality industry: a strategic approach. New York, Chapman \& Hall Ltd.

Benckendorff, P. J., Xiang, Z., \& Sheldon, P. J. (2019). Tourism information technology. Wallingford, Cabi.

Bharadwaj, D. S. (2002). Manpower development for tourism sector in India, tourism in the new millennium, challenges \& opportunities. Cutting edge research in tourism. Chandigarh: Abhishek Publications, 418-428.

Burne, A. \& Maris. S., (2015). "Challenges of Tourism in Today's Society". Revista Latino-Americana De $\begin{array}{llll}\text { Turismologia } & 1 & \text { (1), } & \text { 55-60. }\end{array}$ https://periodicas.ufff.br/index.php/rlaturismologia/articl e/view/9972

Chickering, A. W. (1969). Education and identity. San Francisco: Jossey-Bass. Chickering, A. W., \& Reisser, L. (1993). Education and identity. San Francisco: JosseyBass.

Chickering, A. W. (2000, Spring). Creating community within individual courses. New Directions for Higher Education, 109, 23-32.

Conrady, R., \& Buck, M. (2007). Trends and Issues in Global Tourism... Berlin: Springer.

Corral, V.H.D. \& Rodriguez, J (2015) Tourism Development of Pastaza: weighted participatory strategic diagnosis, Revista Anais Brasileiros de Estudos Turísticos - ABET, e-ISSN 2238-2925, v. 5, n. 2, May / Aug. 2015 - Edição Regular, pp. 1-68.

Dachary, A.C., Burne, S., \& Arnaiz, F. C. (2020). Tourism in Changing Times. Revista Latino-Americana De Turismologia, 6(1). https://doi.org/10.34019/2448198X.2020.v6.33112

DEST, (2007). "Graduate Employability Skills: Prepared for the Business, Industry and Higher Education Collaboration Council", a report by the Australian Chamber of Commerce and Industry and the Business Council of Australia for the Department of Education, Science and Training, Canberra.

Fujimura, H. (2004). Managing the development of one's own vocational skills in Japanese companies. Japan Labor Review, 1(3), 23-44.

Garcia, R. (2013) Space, and Tourism: Contemporary Reflections, Revista Anais Brasileiros de Estudos Turísticos - ABET, e-ISSN 2238-2925, v. 3, n. 2, Jul./Dec., 2013 - Regular Edition, pp. 1-64.

Giancola, F.L. (2009). "Is Total Rewards a Passing Fad?" Compensation \& Benefits Review 41(4): 29-35

Gilster, P., (1997). Digital literacy. New York: Wiley Computer Pub.

Gretzel, U. (2011). Intelligent systems in tourism: A social science perspective. Annals of tourism research, 38(3), 757-779.

Hom, P.W., T.W. Lee, J.D. Shaw, and J.P. Hausknecht. (2017). "One Hundred Years of Employee Turnover Theory and Research." Journal of Applied Psychology 102 (3): 530-545.

Jesuthasan, R. (2017), "HR's new role: rethinking and enabling digital engagement", Strategic HR Review, Vol. 16 No. 2, pp. 60-65. https://doi.org/10.1108/SHR-01-2017-0009

Knight, $\mathrm{P}$ and Yorke, M., (2002). "Employability through the curriculum". A paper prepared for Skills plus Project. June 2002 edition p.16, http://www.open.ac.uk/vqportal/Skills Plus/home.htm

Korstanje, M. E. (2012). Reviewing education concerns. Journal of Hospitality, Leisure, Sport \& Tourism Education, 11(1), 83-85.

Lunt, N. (2006). Employability and New Zealand welfare restructuring. Policy \& Politics, 34(3), 473-494.

Max Starkov, (Mar 6, 2019) Hospitality Digital Technology: Challenges, Priorities, and Buzzwords, https:/www.nextguest.com/blog/hospitality-digital-tech/ 
Milkovich, G.T., J.M. Newman, and B. Gerhart. (2014). Compensation. New York: McGraw-Irwin.

Molz, J. G. (2012). Travel connections: Tourism, technology, and togetherness in a mobile world. Abingdon, Routledge.

Scott, D., T. McMullen, and M. Royal. (2012). "Retention of Key Talent and the Role of Rewards." World at Work Journal 21(1): 58-69.

Sigala, M, (2003) "Unravelling the Impact of Information Communication Technology (ICT) on Restaurant Productivity" ECIS 2002 Proceedings. 164. https://aisel.aisnet.org/ecis2002/164

Silva, R. M. DA; Moreira, F. O. G. (2020) Compliance for protection of human rights in business. Homa Publica
- International Journal on Human Rights and Business, v. 4, n. 1, p. e:057, 30 Jan. 2020

Sin, C., \& Neave, G. (2016). Employability deconstructed: perceptions of Bologna stakeholders. Studies in Higher Education, 41(8), 1447-1462.

Webliography

https://www.encyclopedia.com/social-sciences-andlaw/economics-business-and-labor/businessesand-occupations/McDonalds-corp

https://www.mckinsey.com/ /media/McKinsey/McKinsey\% 20Solutions/Cyber $\% 20$ Solutions/Perspectives $\% 200$ n\%20transforming $\% 20$ cybersecurity/Transforming $\%$ 20cybersecurity March2019.ashx

\section{Processo Editorial / Editorial Process / Proceso Editorial}

Editor Chefe / Editor-in-chief / Editor Jefe: PhD Thiago D. Pimentel (UFJF).

Editores Convidados / Guest Editors / Editores Invitados: PhD Subhash K. B. Pillai (Goa University), PhD Sharad K. Kulshreshtha (North-Eastern Hill University, India) \& PhD Maximiliano Korstanje (Palermo University, Argentina).

Recebido/Received: 26.08.2020; Revisado/Revised: 10.10.2020; Aprovado/Approved: 16.01. 2021; Publicado/Published: 31.01.2021. Seção revisada às cegas por pares / Double-blind peer review section / Sessión revisada por pares ciegos. 